\title{
Epigenetic Regulation of Differentially Expressed Drug-Metabolizing Enzymes in Cancer
}

\author{
Jiaqi Wang, Lushan Yu, Huidi Jiang, Xiaoli Zheng, and Su Zeng \\ Institute of Drug Metabolism and Pharmaceutical Analysis, Zhejiang Province Key Laboratory of Anti-cancer Drug Research, \\ College of Pharmaceutical Sciences, Zhejiang University, Hangzhou, China (J.W., L.Y., H.J., S.Z.) and Hangzhou Cancer Institution, \\ Hangzhou Cancer Hospital, Hangzhou, China (X.Z.)
}

Received March 12, 2020; accepted June 1, 2020

\begin{abstract}
Drug metabolism is a biotransformation process of drugs, catalyzed by drug-metabolizing enzymes (DMEs), including phase I DMEs and phase II DMEs. The aberrant expression of DMEs occurs in the different stages of cancer. It can contribute to the development of cancer and lead to individual variations in drug response by affecting the metabolic process of carcinogen and anticancer drugs. Apart from genetic polymorphisms, which we know the most about, current evidence indicates that epigenetic regulation is also central to the expression of DMEs. This review summarizes differentially expressed DMEs in cancer and related epigenetic changes, including DNA methylation, histone modification, and noncoding RNAs. Exploring the epigenetic regulation of differentially expressed DMEs can provide a basis for implementing
\end{abstract}

individualized and rationalized medication. Meanwhile, it can promote the development of new biomarkers and targets for the diagnosis, treatment, and prognosis of cancer.

\section{SIGNIFICANCE STATEMENT}

This review summarizes the aberrant expression of DMEs in cancer and the related epigenetic regulation of differentially expressed DMEs. Exploring the epigenetic regulatory mechanism of DMEs in cancer can help us to understand the role of DMEs in cancer progression and chemoresistance. Also, it provides a basis for developing new biomarkers and targets for the diagnosis, treatment, and prognosis of cancer.

\section{Introduction}

With an increasing incidence and mortality every year, cancer is a major public problem worldwide and is one of the most deathful diseases for both men and women. In the United States, prostate, lung, and colorectal cancers are three major cancers in men, whereas the three most common cancers in women are breast, lung, and colorectal cancers (Siegel et al., 2019). The high cancer mortality rate is because of a combination of factors, including the lack of reliable biomarkers for cancer diagnosis, drug resistance, and deficiency in effective targeted treatment.

Drug metabolism is a biotransformation process of drugs that is usually mediated by specific enzymes (Almazroo et al., 2017). The drug-metabolizing pathways mediated by drug-metabolizing enzymes (DMEs) are classified into phase I (functionalization) and phase II (conjugation) reactions. Phase I reactions are the redox or hydrolysis process of the drug to activate or detoxify it, which are mainly mediated

This work was supported by the National Key R\&D Program of China [2017YFC0908600] and [2017YFE0102200], the National Natural Science Foundation of China [81702801]; and Leading Talent of "Ten Thousand Plan"National High-Level Talents Special Support Plan.

https://doi.org/10.1124/dmd.120.000008. by phase I DMEs, including cytochrome P450 enzymes (P450s), Flavincontaining monooxygenases, alcohol dehydrogenases (ADHs), and aldehyde dehydrogenases. P450s comprise $70 \%-80 \%$ of all phase I DMEs (Nebert and Dalton, 2006). The P450 superfamily can be divided into two parts; CYP1-4 families are responsible for the biotransformation of most xenobiotic compounds, whereas CYP7-51 families are mainly involved in the metabolism of endogenous substances in a substrate-specific manner. Most P450s are located in the liver, resulting in its strong detoxification effect. The most abundantly expressed P450 isoforms in the liver are CYP3A4, 2C9, 2C8, 2E1, and 1A2, whereas CYP2A6, 2D6, 2B6, 2C19, and 3A5 are less abundant (Zanger and Schwab, 2013). P450s, including CYP2C9, 2C19, 3A4, and 3A5, are also distributed in mature intestinal epithelial cells and are responsible for intestinal metabolism. Besides, some P450s such as CYP1A1 and 1B1 mainly express extrahepatically, which are in accordance with their metabolic roles of environmental pollutants and endogenous compounds. In phase II reactions catalyzed by phase II DMEs, the products from phase I pathways conjugate with a hydrophilic endogenous compound. After conjugation, the substances are converted into water-soluble products, which are easy to excrete. Most of phase II DMEs consist of transferases, including UDP-glucuronosyltransferases

ABBREVIATIONS: ADH, alcohol dehydrogenase; ADT, androgen deprivation therapy; AhR, aryl hydrocarbon receptor; BERA, bioengineered RNA agent; BET, bromodomain-containing proteins; circRNA, circular RNA; CpG, phosphoric acid-guanine; CTX, cyclophosphamide; 1, 25-D3; $1 \alpha$, 25dihydroxyvitamin D3; DME, drug-metabolizing enzyme; DNMT, DNA methyltransferase; GST, glutathione S-transferase; HCC, hepatocellular carcinoma; HDAC, histone deacetylase; IncRNA, long noncoding RNA; miRNA, microRNA; NAT, N-acetyltransferase; ncRNA, noncoding RNA; NNK, 4-methylnitrosamino-I-3-pyridyl-butanone; P450, cytochrome P450; PAH, polycyclic aromatic hydrocarbon; SULT, sulfotransferase; Tet, teneleven translocation; TSA, trichostatin A; UGT, UDP-glucuronosyltransferase. 
(UGTs), sulfoctransferases (SULTs), glutathione S-transferases (GSTs), and N-acetyltransferases (NATs) (Almazroo et al., 2017). Phase II DMEs are mostly located in the liver and kidney. UGTs are major members of phase II DME, which mediate glucuronidation and elimination of a variety of endogenous and exogenous substances and are considered integral parts of detoxification enzymes in the human body (Pathania et al., 2018). GSTs catalyze the conjugation reactions of nucleophilic glutathione with various electronic xenobiotics, thus facilitating their elimination and protecting cells from oxidative stress and other stimuli (Pljesa-Ercegovac et al., 2018). The abnormal expression of DMEs may lead to changes in the metabolism of drugs or procarcinogens, thus causing diseases. It also brings a considerable challenge for individualized treatment by affecting the metabolic process and adverse effects.

Epigenetics is the study of heritable changes in gene expression without any alternation in the DNA sequence. The main contents of epigenetics include DNA methylation, histone modification, and noncoding RNAs (ncRNAs) (Ivanov et al., 2012; Zanger et al., 2014). Many factors can influence Epigenetic regulation, such as age, diet, lifestyle, environment, and disease. Accumulating evidence demonstrates that epigenetic modification changes a lot during tumorigenesis. DNA methylation and histone modification patterns of some genes, as well as the expression of ncRNAs, are expected to be biomarkers for early detection, diagnosis, prognosis, drug disposition, and clinical response of cancer (Chen et al., 2013; Xu et al., 2017; Tan et al., 2018). Reversing gene expression in cancer by changing the abnormal epigenetic modification also provides a new train of thought for the treatment of cancer (Lachenmayer et al., 2012; Liu et al., 2016). This review will give a brief summary of abnormal expression of DMEs in cancer and epigenetic regulation of differential expression of DMEs.

\section{Differential Expression of DMEs in Cancer}

P450s are the most abundant family of DMEs, expressing in almost all organs. P450s are involved in the metabolic inactivation of endogenous and exogenous compounds. However, in some instances, they also mediate the metabolic activation of many carcinogens, which increase the risk of cancer. CYP1A1 and CYP1B1 are causally implicated in activation of procarcinogens such as polycyclic aromatic hydrocarbons (PAHs). CYP2A6, CYP2A13, and CYP2E1 can metabolize nitrosamines into unstable metabolites, which can form diazonium ions. CYP2E1 is also involved in the metabolic activation of tetrachloromethane, accompanying the production of free radicals (He and Feng, 2015). CYP3A4 participates in the metabolic activation and detoxification of hepatic carcinogen aflatoxin B1 and is tightly related to the carcinogenesis of hepatocellular carcinoma induced by aflatoxin B1 (Kamdem et al., 2006).

Emerging evidence indicates that DMEs play an essential role in the formation, prevention, metastasis, and treatment of cancer (Alzahrani and Rajendran, 2020). The high expression of some DMEs is commonly considered a reason for carcinogenesis, metastasis, and chemoresistance because of the increased activation of procarcinogens and inactivation of anticancer drugs. For instance, the high expression of CYP1A1 promotes the activation of $\mathrm{PAH}$, and the active metabolites covalently bond to DNA and produce DNA adducts, which eventually leads to DNA damage and tumorigenesis (Moorthy et al., 2015). The overexpression of CYP2J2 in cancer cell lines brings on increased four regioisomeric epoxyeicosatrienoic acids, which promote cancer metastasis (Jiang et al., 2007). Besides, dihydropyrimidine dehydrogenase is pivotal to the catabolism of Fluorouracil, so the upregulation of dihydropyrimidine dehydrogenase can reduce the activity of cyclophosphamide (CTX) greatly (Pathania et al., 2018). The abnormal low expression of DMEs is also a risk factor for tumor initiation. Some DMEs act on carcinogen and play a detoxifying role, so the repression of them cause tumor growth. For prodrugs that require DMEs for metabolic activation, the repression of these DMEs can also cause drug resistance. CTX, a broad-spectrum antineoplastic prodrug, is converted to its active form by CYP2B6 and 3A4 (Lindley et al., 2002). Therefore, the suppression of these P450s will materially affect the efficacy of CTX. The aberrant expression of DMEs occurs in several cancer types, including liver, prostate, and lung cancers. A summary of the differentially expressed DMEs and their functions is listed in Table 1.

Liver Cancer. The liver is the most vital organ for drug biotransformation and is rich in DMEs. The expression and activity of DMEs can be modulated by several factors, such as genetic polymorphisms and disease states. It has been confirmed that the metabolism activities of P450 isoforms are severely impaired in patients with hepatocellular carcinoma (HCC) by investigating the activities of major P450s in microsomes from normal and HCC liver tissue samples (Yan et al., 2015b).

Several studies represent a series of evidence implicating that the expression of DMEs changed in HCC samples. Because of the decrease of functional hepatocytes in HCC, most of the phase I and phase II metabolizing enzymes are expressed at lower levels compared with noncancerous liver tissues, including CYP1A2, CYP2A6, CYP2B6, CYP2C8, CYP2C9, CYP2C19, CYP2D6, CYP3A4, CYP3A5, CYP3A7, CYP4A11, NAT1, NAT2, UGT1A1, UGT1A4, UGT1A9, and UGT2B7 (Chen et al., 2014; Lu et al., 2015; Yan et al., 2015a,b). The silence of CYP2C19 expression in hepatitis B virus-infected patients with HCC is reported to be regulated by e-box methylation of the constitutive androstane receptor (Tang et al., 2016). The dysregulation of DMEs in HCC is a pivotal reason for clinical chemotherapy failure (Ul-Islam et al., 2018). The expression of DMEs is also associated with the risk of liver cancer. CYP2E1 is related to the activation of many toxicants. The high expression of CYP2E1 is recognized as a risk factor for hepatic fibrosis (Guo et al., 2019). The research revealed that hepatic fibrotic rats with higher CYP2E1 activity develop a more severe form of HCC (Gao et al., 2018). Besides, CYP2E1 also participates in the formation of etheno-DNA adducts, which are potent carcinogens of liver cancer (Linhart et al., 2014). GSTs are detoxifying enzymes and play a predominant role in cell protection. A meta-analysis suggested that the inactivation of GSTP1 in HCC correlates with the hepatocarcinogenesis (Li et al., 2018).

Lung Cancer. The lung is the main organ exposed to the inhaled chemical toxicants and carcinogens, so the metabolizing enzymes that participate in xenobiotic metabolism are essential for respiratory protection (Leclerc et al., 2010). In some instances, they can convert procarcinogens to active metabolites. These active intermediates can form DNA adducts, cause gene mutation, and eventually lead to cancer (Castell et al., 2005). The increase of CYP1A1 activity contributes to the metabolic activation and carcinogenicity of PAHs. The researchers designed a liposome-based CYP1A1 silencing nanomedicine, showing the potential for the treatment of lung cancer (Zhang et al., 2019). CYP1B1 catalyzes the activation of $\mathrm{N}$-nitrosamines such as 4-methylnitrosamino-1-3-pyridyl-butanone (NNK). NKK can also induce CYP1B1 expression, thus accelerating lung cancer progression ( $\mathrm{Li}$ et al., 2015b). GSTM2 is a detoxifying enzyme that expressed a low level in lung cancer cells (Tang et al., 2011). The mRNA expression level of DMEs in pulmonary parenchyma, bronchial mucosa, and tumoral lung tissues were detected using a high throughput quantitative real-time reverse-transcription polymerase chain reaction method. It is demonstrated that ADH1B, CYP3A7, and CYP4B1 show decreased mRNA levels in lung cancer (Leclerc et al., 2011).

Prostate Cancer. Prostate cancer is the most common cancer that occurs in men, which is mostly androgen-dependent. Androgen deprivation therapy (ADT) is still the first-line treatment of metastatic prostate cancer (Litwin and Tan, 2017). UGT2B15 and UGT2B17 are involved in androgen inactivation in prostate cells (Pâquet et al., 2012). 
TABLE 1

List of differentially expressed DMEs during carcinogenesis and their functions

\begin{tabular}{|c|c|c|c|c|c|}
\hline Cancer type & Variation Trend & Functional Classification & DMEs & Roles in Cancer & Reference \\
\hline \multirow[t]{8}{*}{ Liver cancer } & Upregulation & $\begin{array}{l}\text { Increased activation of } \\
\text { procarcinogens }\end{array}$ & CYP1B1 & $\begin{array}{l}\text { CYP1B1 increases the HCC risk and associated } \\
\text { with the activation of procarcinogens. }\end{array}$ & $\begin{array}{l}\text { Su et al., 2007; Liu } \\
\text { et al., } 2015\end{array}$ \\
\hline & \multirow[t]{7}{*}{ Downregulation } & $\begin{array}{l}\text { Potential impact on } \\
\text { drug efficacy and } \\
\text { toxicity }\end{array}$ & $\begin{array}{l}\text { CYP1A2, CYP2A6, } \\
\text { CYP2B6, CYP2C8, } \\
\text { CYP2C9, CYP2C19, } \\
\text { CYP2D6, CYP3A4, } \\
\text { CYP3A5 }\end{array}$ & $\begin{array}{c}\text { They are responsible for the metabolism of various } \\
\text { drugs. Because of the decrease of functional } \\
\text { hepatocytes, their expressions are downregulated, } \\
\text { which may reduce drug efficacy and increase drug } \\
\text { toxicity. }\end{array}$ & $\begin{array}{l}\text { Chen et al., 2014; Yan } \\
\text { et al., 2015a; Hu et al., } \\
2019\end{array}$ \\
\hline & & \multirow[t]{2}{*}{$\begin{array}{l}\text { Potential biomarkers } \\
\text { in cancer }\end{array}$} & CYP2E1 & $\begin{array}{c}\text { CYP2E1 activity decreases during } \\
\text { hepatocarcinogenesis, the specific mechanism } \\
\text { remains unknown. }\end{array}$ & Ho et al., 2004 \\
\hline & & & CYP11A1 & $\begin{array}{l}\text { The loss of CYP11A1 contributes to abnormal } \\
\text { steroid synthesis. }\end{array}$ & Fan et al., 2016 \\
\hline & & \multirow[t]{4}{*}{$\begin{array}{l}\text { Decreased inactivation } \\
\text { of carcinogens }\end{array}$} & CYP26A1 & $\begin{array}{l}\text { CYP26A1 participates in the inactivation of retinoic } \\
\text { acid, which may promote HCC progression. }\end{array}$ & Brodeur et al., 2019 \\
\hline & & & NAT1, NAT2 & $\begin{array}{l}\text { They are responsible for the biotransformation of } \\
\text { most arylamine and hydrazine substrates. }\end{array}$ & $\begin{array}{l}\text { Yu et al., 2000; Hu } \\
\text { et al., } 2019\end{array}$ \\
\hline & & & $\begin{array}{l}\text { UGT1A1, UGT1A4, } \\
\text { UGT1A9, UGT2B7 }\end{array}$ & $\begin{array}{l}\text { These UGTs detoxify endogenous and } \\
\text { environmental carcinogens through glucuronidation } \\
\text { reaction. }\end{array}$ & $\begin{array}{l}\text { Lu et al., 2015; Yan } \\
\text { et al., 2015b }\end{array}$ \\
\hline & & & GSTP1 & $\begin{array}{l}\text { GSTP1 is a detoxifying enzyme that protects cells } \\
\text { from various stimuli such as hypoxia and oxidative } \\
\text { stress. }\end{array}$ & $\begin{array}{l}\text { Tchou et al., } 2000 ; \mathrm{Li} \\
\quad \text { et al., } 2018\end{array}$ \\
\hline \multirow[t]{6}{*}{ Lung cancer } & \multirow[t]{3}{*}{ Upregulation } & $\begin{array}{l}\text { Catabolism of } \\
\text { antiproliferation } \\
\text { compound }\end{array}$ & CYP24A1 & $\begin{array}{l}\text { CYP24A1 catabolizes the antiproliferation } \\
\text { compound } 1,25-\mathrm{D} 3 \text {. }\end{array}$ & Chen et al., 2011b \\
\hline & & $\begin{array}{l}\text { Increased activation of } \\
\text { procarcinogens }\end{array}$ & CYP1A1, CYP1B1 & $\begin{array}{l}\text { They catalyze the activation of carcinogens related } \\
\text { to tobacco use, such as NNK and PAHs. }\end{array}$ & $\begin{array}{l}\text { Li et al., 2015b; Zhang } \\
\text { et al., } 2019\end{array}$ \\
\hline & & & CYP19A1 & $\begin{array}{l}\text { CYP19A1 is an estrogen synthesis enzyme that can } \\
\text { promote the steroidal growth-stimulatory pathway. }\end{array}$ & Weinberg et al., 2005 \\
\hline & \multirow[t]{3}{*}{ Downregulation } & $\begin{array}{l}\text { Potential biomarkers } \\
\text { in cancer }\end{array}$ & ADH1B & $\begin{array}{l}\text { ADH1B is indispensable in the metabolism of fatty } \\
\text { acids, retinoid, and ethanol, which are associated } \\
\text { with lung cancer. }\end{array}$ & Mutka et al., 2012 \\
\hline & & & $\begin{array}{l}\text { CYP3A7, CYP4B1 } \\
\text { CYP11A1 }\end{array}$ & $\begin{array}{l}\text { The specific role is not clear. } \\
\text { The loss of CYP11A1 contributes to abnormal } \\
\text { steroid synthesis. }\end{array}$ & $\begin{array}{l}\text { Leclerc et al., } 2011 \\
\text { Fan et al., } 2016\end{array}$ \\
\hline & & $\begin{array}{l}\text { Decreased inactivation } \\
\text { of carcinogens }\end{array}$ & GST-M2 & $\begin{array}{l}\text { GST-M2 is a detoxifying enzyme that can protect } \\
\text { lung cells from DNA damage. }\end{array}$ & Tang et al., 2011 \\
\hline \multirow[t]{7}{*}{ Prostate cancer } & \multirow[t]{3}{*}{ Upregulation } & $\begin{array}{l}\text { Increased activation of } \\
\text { procarcinogens }\end{array}$ & CYP1A1 & $\begin{array}{l}\text { CYP1A1 mediates the metabolic activation of } \\
\text { procarcinogens PAHs. }\end{array}$ & Mitsui et al., 2016 \\
\hline & & $\begin{array}{l}\text { Elimination of } \\
\text { anticancer drugs }\end{array}$ & CYP1B1 & $\begin{array}{l}\text { CYP1B1 metabolizes estradiol to carcinogen } \\
\text { 4-hydroxy estradiol and is related to the resistance } \\
\text { to docetaxel. }\end{array}$ & Pastina et al., 2010 \\
\hline & & $\begin{array}{l}\text { Potential biomarkers } \\
\text { in cancer }\end{array}$ & UGT2B17 & $\begin{array}{l}\text { UGT2B17 is responsible for the elimination of the } \\
\text { inactive metabolites androstane- } 3 \alpha \text {-diol and } \\
\text { androsterone. It is also associated with metastasis. }\end{array}$ & $\begin{array}{l}\text { Pâquet et al., 2012; } \\
\text { Lévesque et al., } 2020\end{array}$ \\
\hline & \multirow[t]{4}{*}{ Downregulation } & $\begin{array}{l}\text { Decreased inactivation } \\
\text { of carcinogens }\end{array}$ & CYP3A4, CYP2B6 & $\begin{array}{l}\text { They are key inactivators of testosterone which are } \\
\text { significantly related to the development of prostate } \\
\text { cancer. }\end{array}$ & $\begin{array}{l}\text { Kumagai et al., 2007; } \\
\text { Fujimura et al., } 2009\end{array}$ \\
\hline & & & GSTP1 & $\begin{array}{l}\text { The loss of GSTP1 leads to an increase of } \\
\text { intracellular reactive oxygen species (ROS) and } \\
\text { DNA damage; promotes the occurrence of cancer. }\end{array}$ & $\begin{array}{l}\text { Hokaiwado et al., 2008; } \\
\text { Kanwal et al., } 2014\end{array}$ \\
\hline & & & UGT2B15 & $\begin{array}{l}\text { UGT2B15 is a negatively regulated target gene in } \\
\text { castration-resistant prostate cancer (CRPC), } \\
\text { inactivating the active androgen } \\
\text { dihydrotestosterone in prostate cells. }\end{array}$ & Pâquet et al., 2012 \\
\hline & & $\begin{array}{l}\text { Potential biomarkers } \\
\text { in cancer }\end{array}$ & CYP11A1 & $\begin{array}{l}\text { The loss of CYP11A1 contributes to abnormal } \\
\text { steroid synthesis. }\end{array}$ & Fan et al., 2016 \\
\hline \multirow[t]{3}{*}{ Breast cancer } & \multirow[t]{2}{*}{ Upregulation } & $\begin{array}{l}\text { Increased activation of } \\
\text { procarcinogens }\end{array}$ & CYP1B1 & $\begin{array}{l}\text { CYP1B1 metabolizes estradiol to carcinogen } \\
\text { 4-hydroxy estradiol, resulting in DNA adducts. }\end{array}$ & Gajjar et al., 2012 \\
\hline & & Promote tumor growth & CYP4Z1 & $\begin{array}{l}\text { CYP4Z1 is a fatty acid hydroxylase that promotes } \\
\text { angiogenesis and the development of breast cancer. }\end{array}$ & Yu et al., 2012 \\
\hline & Downregulation & $\begin{array}{l}\text { Decreased inactivation } \\
\text { of carcinogens }\end{array}$ & GSTP1 & GSTP1 detoxifies carcinogens and cytotoxic drugs. & $\begin{array}{l}\text { Schnekenburger et al., } \\
2014\end{array}$ \\
\hline Kidney cancer & Downregulation & $\begin{array}{l}\text { Potential impact on } \\
\text { drug efficacy and } \\
\text { toxicity }\end{array}$ & UGT1A9, UGT2B7 & $\begin{array}{l}\text { UGT1A9 and UGT2B7 are responsible for the } \\
\text { clearance of drugs such as propofol and sorafenib in } \\
\text { the kidney. }\end{array}$ & Margaillan et al., 2015 \\
\hline $\begin{array}{l}\text { Esophageal } \\
\text { cancer }\end{array}$ & Upregulation & Promote tumor growth & CYP2C9 & $\begin{array}{l}\text { CYP2C9 promotes the proliferation of early } \\
\text { esophageal cancer. }\end{array}$ & Schmelzle et al., 2011 \\
\hline \multirow[t]{2}{*}{ Ovarian cancer } & \multirow[t]{2}{*}{ Upregulation } & $\begin{array}{l}\text { Increased activation of } \\
\text { procarcinogens }\end{array}$ & CYP1B1 & $\begin{array}{l}\text { CYP1B1 metabolizes estradiol to carcinogen } \\
\text { 4-hydroxy estradiol. }\end{array}$ & Gajjar et al., 2012 \\
\hline & & $\begin{array}{l}\text { Elimination of } \\
\text { anticancer drugs }\end{array}$ & GSTP1 & $\begin{array}{l}\text { GSTP1 is closely related to the chemoresistance of } \\
\text { platinum drugs. }\end{array}$ & Sawers et al., 2014 \\
\hline
\end{tabular}


TABLE 1-Continued

\begin{tabular}{|c|c|c|c|c|c|}
\hline Cancer type & Variation Trend & Functional Classification & DMEs & Roles in Cancer & Reference \\
\hline \multirow[t]{2}{*}{$\begin{array}{l}\text { Colorectal } \\
\text { cancer }\end{array}$} & Upregulation & $\begin{array}{l}\text { Increased activation of } \\
\text { procarcinogens }\end{array}$ & CYP1A1 & $\begin{array}{l}\text { CYP1A1 participates in the metabolic activation of } \\
\text { PAHs in tobacco and increases the risk of colorectal } \\
\text { cancer. }\end{array}$ & Slattery et al., 2004 \\
\hline & & & CYP2E1 & $\begin{array}{c}\text { CYP2E1 is involved in the metabolic activation of } \\
\text { potent carcinogens azoxymethane and } \\
\text { methylazoxymethanol. }\end{array}$ & Sohn et al., 2001 \\
\hline \multirow[t]{2}{*}{ Bladder cancer } & Upregulation & $\begin{array}{l}\text { Increased activation of } \\
\text { procarcinogens }\end{array}$ & CYP4B1 & $\begin{array}{l}\text { CYP4B1 metabolic activates the carcinogen } \\
\text { 2-aminofluorene. }\end{array}$ & Imaoka et al., 2000 \\
\hline & Downregulation & $\begin{array}{l}\text { Potential biomarkers } \\
\text { in cancer }\end{array}$ & CYP1A1, CYP1B1 & $\begin{array}{c}\text { Metabolomic profiling revealed their deficiency in } \\
\text { bladder cancer; the specific mechanism remains } \\
\text { unknown. }\end{array}$ & Putluri et al., 2011 \\
\hline $\begin{array}{l}\text { Hematologic } \\
\text { malignancy }\end{array}$ & Upregulation & $\begin{array}{c}\text { Increased activation of } \\
\text { procarcinogens }\end{array}$ & CYP2J2 & $\begin{array}{l}\text { CYP2J2 converts arachidonic acid to carcinogen } \\
\text { epoxyeicosatrienoic acids and promotes cancer } \\
\text { growth. }\end{array}$ & Chen et al., 2011a \\
\hline
\end{tabular}

Some studies have found that UGT2B17 deletion polymorphism is related to prostate cancer susceptibility (Karypidis et al., 2008). UGT2B15 and UGT2B17 differentially expressed during prostate cancer progression (Pâquet et al., 2012). Besides, P450s are key inactivators of testosterone in the prostate. It was reported that decreased CYP2B6 and CYP3A4 are significantly related to the development and poor prognosis of prostate cancer (Kumagai et al., 2007; Fujimura et al., 2009). After continuous ADT, these cancers may become androgen-independent and resistant to ADT. In this process, the expression of GST- $\pi$ increases, indicating its role in the development of prostate cancer (Hokaiwado et al., 2008).

Kidney Cancer. In the kidney, UGT expression is related to the clearance of many xenobiotics. A proteomic study reported that UGT1A6, UGT1A9, and UGT2B7 are the most abundant UGT subtypes in the kidney. The mRNA and protein levels of UGT1A9 and UGT2B7 are significantly downregulated in tumor kidneys, accompanied by decreased glucuronidation capacity (Margaillan et al., 2015).

Esophageal Cancer. A study revealed the potential clinical relevance between the expression of CYP2C9 and esophageal cancer. The expression of CYP2C9 in esophageal adenocarcinoma and adjacent esophageal mucosa was higher compared with esophageal squamous cell carcinoma. CYP2C9 is likely to promote esophageal cancer proliferation (Schmelzle et al., 2011).

Other Hormone-Induced Cancers. Some DMEs are relevant to the metabolism of hormones, so the aberrant expression of these DMEs may occur in hormone-induced cancers. CYP1B1 is mainly responsible for the metabolism of estradiol, forming carcinogens 4-hydroxy estradiol. The enrichment of 4-hydroxy estradiol in breast, ovarian, and prostate is considered an increased risk for developing cancers (Yager, 2000). CYP1B1 is causally implicated in the carcinogenesis of breast cancer, ovarian cancer, prostate cancer, and lung cancer. CYP1B1 expression increases in estrogen-related tumors but is very low in normal tissues (McFadyen et al., 1999; Carnell et al., 2004; Gajjar et al., 2012). The CYP11 subfamily is responsible for steroid biosynthesis (Thomas, 2007). The downregulation of CYP11A1 in cancers may affect the biosynthesis of steroids. Data obtained from The Cancer Gene Atlas database revealed that CYP11A1 is significantly downregulated in six cancers types, including colon adenocarcinoma, renal clear cell carcinoma, hepatocellular carcinoma, lung squamous cell carcinoma, prostate adenocarcinoma, and uterine corpus endometrial carcinoma (Fan et al., 2016).

\section{Epigenetic Regulation of Differentially Expressed DMEs in Cancer}

\section{DNA Methylation}

DNA methylation is a dynamic process involving methylation and demethylation. DNA methyltransferase (DNMT) 1, 3A, and 3B can transfer a methyl group to the cytosine at cytosine-phosphoric acidguanine $(\mathrm{CpG})$ motif to form 5-methylcytosine. Passive or active DNA demethylation can reverse DNA methylation patterns. Passive DNA demethylation is likely to be because of the reduction or inhibition of DNA methyltransferase, so the DNA methylation status cannot maintain during DNA replication (Piccolo and Fisher, 2014). Active DNA demethylation is mainly mediated by activation-induced cytidine deaminase/apolipoprotein B mRNA-editing enzyme complex or ten-eleven translocation (Tet) enzymes Tet1, Tet2, and Tet3. Methyl-CpG binding proteins can recognize 5-methylcytosine, which has a high affinity for 5methylcytosine. Methyl-CpG binding proteins cause chromatin structure modification and remodeling by recruiting corepressor complexes such as histone deacetylase (HDAC) to methylated promoter regions, thus reducing gene expression (Clouaire and Stancheva, 2008). DNA methylation plays a critical role in gene expression and chromatin remodeling. It can repress gene expression by changing the chromatin structure directly, hindering transcription factor, or coactivator binding to the promoter region of the target gene (Moore et al., 2013).

It has been widely reported that DNA methylation is involved in the regulation of differentially expressed DMEs in tumors. In tumors, the methylation status of $\mathrm{CpG}$ islands in the gene promoter regions is closely related to the expression level of the target gene. Abnormal DNA methylation in tumors and normal tissues can be detected in body fluids such as blood and urine, indicating that DNA methylation is expected to be a biomarker for liquid biopsy, which can be used for diagnosis and monitoring of cancer. Also, the abnormal expression of DNA methyltransferase may occur in the process of cancer development and affect the expression level of DMEs, thus promoting the development of cancer. Therefore, DNA methyltransferase is a potential therapeutic target of cancer. Changing the expression of DNA methyltransferase may reverse the expression of DMEs in cancer. DNA methylation inhibitor decitabine (5-aza-2'-deoxycytidine) has been approved by the US Food and Drug Administration for the treatment of hematologic malignancies (Nie et al., 2014).

Besides, considering the importance of DMEs toward personalized medicine, Genome-wide integrative analysis was used to analyze the DNA methylation and mRNA expression profiles of human tissues and hepatoma cells, which revealed that some DME genes, including CYP1A2, CYP2C19, CYP2D6, GSTA4, GSTM5, GSTT1, and SULT1A1 are regulated by DNA methylation, potentially leading to individual differences in drug metabolism (Habano et al., 2015).

\section{Hypomethylation Status of DME Genes in Cancer}

DNA hypomethylation is always considered the main reason for highlevel gene expression. Some DMEs are responsible for the metabolic 
activation of environmental toxicants and carcinogens; their high expression can contribute to cancer progression. Meanwhile, some DMEs can metabolically inactivate anticancer drugs, thus causing chemoresistance (Fig. 1).

CYP1A1 can activate multiple carcinogens and therefore promote cancer progression. The expression and methylation status were detected in prostate cancer cells. CYP1A1 expression is higher in cancer cells compared with normal cells. When treated with decitabine, the expression of CYP1A1 become much higher (Mitsui et al., 2016). In breast cancer cell line MCF-7 and T47D, estrogen receptor $\alpha$ can repress the expression of CYP1A1 through recruiting DNMT3b(Marques et al., 2013).

Aberrant DNA methylation status of $C Y P 1 B 1$ has been observed in several hormone-related cancer types, such as prostate cancer and breast cancer. The methylation status of $C Y P 1 B 1$ was analyzed in prostate cancer tissues and benign prostatic status hyperplasia samples; the results revealed that methylation of its promoter/enhancer region was much lower in prostate cancer, which may play a role in cancer development. It is well known that CYP1B1 is induced by the aryl hydrocarbon receptor (AhR) and AhR nuclear translocator directly. When treated with DNA methyltransferase inhibitor, 5-Aza-dC, no cell line showed a significant change of the expression of AhR and AhR nuclear translocator, indicating that $\mathrm{CpG}$ methylation of $C Y P 1 B 1$ promoter is key to its expression (Tokizane et al., 2005). Moreover, considering the function of metabolizing estradiol and tamoxifen, $C Y P 1 B 1$ hypomethylation is perceived as a carcinogenic factor as well as predictive markers for response to tamoxifen therapy in breast cancer (Widschwendter et al., 2004).

UGT1A1 is a critical phase II metabolizing enzyme involved in the metabolic inactivation of SN38, the active metabolite of irinotecan. Irinotecan is a first-line drug for the treatment of metastatic colorectal cancer (Hahn et al., 2019), so the hypomethylation status of UGT1A1 may accelerate the inactivation of irinotecan to reduce the efficacy of irinotecan. Bisulfite sequencing of UGTIAl observed the abnormal methylation modification of specific $\mathrm{CpG}$ islands in UGT1A1-negative cells such as HCT-116, HCT-15, and COLO-320DM, whereas in HT29, HT-115, and LOVO cell lines with high expression of UGT1A1, these sites were in the hypomethylation states. Methylation of the UGT1A1 promoter can repress its transcriptional activity completely. A combination of DNA methyltransferase inhibitor and histone deacetylase inhibitor can reverse the hypermethylation and restore the expression of UGT1A1 in UGT1A1 negative cells (Gagnon et al., 2006). Another research investigated the correlation between UGT1A1 expression and its sensitivity to irinotecan in seven colorectal cell lines. The cell lines with low UGT1A1 expression are more sensitive to irinotecan. The methylation status of UGT1A1 can obviously affect the cytotoxicity of irinotecan (Xie et al., 2014).

\section{Hypermethylation Status of DME Genes in Cancer}

In general, DNA hypermethylation suppresses the expression of DMEs, which are involved in detoxification. It is causally implicated in the occurrence and development of cancer (Fig. 1).

As we mentioned before, $C Y P 1 B 1$ hypomethylation was observed in several hormone-related cancers. However, the hypermethylation status of the CYP1B1 promoter can be found in colon cancer (Habano et al., 2009), bladder cancer (Putluri et al., 2011), and adolescents with acute lymphocytic leukemia(DiNardo et al., 2013), indicating a worse outcome. Metabolic profiling revealed that $C Y P 1 B 1$ hypermethylation could also be found in body fluids such as urine, suggesting it might be a potential biomarker for distinguishing benign bladder and bladder cancer (Putluri et al., 2011).

GSTs are significant phase II detoxification enzymes. GST-M2, a member of GST subfamily $\mu$-class GST, has special clinical features.
The activity of GST-M2 in human normal embryonic lung fibroblast MRC-5 is significantly higher than in lung cancer cell line H1355. The catalytic activity of GST-M2 is closely related to DNA damage induced by carcinogens (Weng et al., 2005). The low expression of GST-M2 in lung cancer cell lines can be reversed after treatment with DNMT inhibitor decitabine. The $\mathrm{CpG}$ islands on the GST-M2 promoter are highly methylated. It is demonstrated that in lung cancer tissues, the low expression of GST-M2 is accompanied by high expression of DNMT3b, indicating a close relationship between DNA methylation and GST-M2 expression. GST-M2 expression in lung cancer cell lines can be induced after silencing DNMT3b. Consequently, the expression of GST-M2 in lung cancer cells is negatively regulated by DNA methylation. $\mathrm{CpG}$ hypermethylation of GST-M2 blocks the binding of transcription factor specificity protein to $G S T-M 2$ promoter, thus inhibiting the transcription of GST-M2 (Tang et al., 2011). GST-M2 hypermethylation is also investigated in Barrett's adenocarcinoma and pancreatic cancers (Peng et al., 2009; Tan et al., 2009).

GSTP1, the gene encoding the $\pi$-class GST, is repressed in multiple cancer subtypes, including solid tumors such as prostate (Henrique and Jerónimo, 2004), breast (Fang et al., 2015), liver (Revill et al., 2013), lung cancers (Gao et al., 2009), and hematologic malignancies, because of $\mathrm{CpG}$ island hypermethylation in the promoter regions. The aberrant methylation status of the GSTP1 promoter is regarded as a specific marker for prostate cancer and can be found in at least $90 \%$ of prostate cancers (Nakayama et al., 2004). It has been reported that GSTP1 promoter methylation may increase the incidence and recurrence of prostate cancer (Maldonado et al., 2014; Zhou et al., 2019). Besides, GSTP1 CpG island hypermethylation can also be detected in the urine and plasma from patients with prostate cancer. This means that GSTP1 $\mathrm{CpG}$ island hypermethylation can be used as a biomarker for the diagnosis and prognosis of prostate cancer. In a recent study, a sensitive methylation-specific polymerase chain reaction assay was applied to detect the serum-free methylated GSTP1 DNA in patients with metastatic castration-resistant prostate cancer. It has been demonstrated that the expression of serum-free methylated GSTP1 is closely correlated with overall survival and response to docetaxel in metastatic castrationresistant prostate cancer (Mahon et al., 2019).

NAT1 is a phase II metabolizing enzyme that is responsible for the biotransformation of most arylamine and hydrazine substrates. Several studies have shown that NAT1 can influence the development and drug resistance of breast cancer (Rodrigues-Lima et al., 2010). The frequency of NAT1 methylation was significantly lower in the control group compared with the tamoxifen-resistant breast cancer group. The hypermethylation of the NAT1 gene may affect the initiation of tamoxifen resistance in breast cancer (Kim et al., 2010).

\section{Histone Modification}

Histones are the basic structural proteins of chromatin. Histone octamer consists of two copies each of histones H2A, H2B, H3, and H4, which are wrapped with 147 base pairs of DNA. Histone is a basic protein because it contains a high proportion of basic amino acids such as lysine and arginine. The $\mathrm{N}$ terminal of histone is dissociated from the nucleosome, so the specific amino acid residues can be modified by methylation, acetylation, phosphorylation, ubiquitination, and similar processes. The chromatin structure changed after modification, thus regulating the gene transcription (Luger et al., 2012). Aberrant histone modifications may lead to abnormal gene expression in cancer. Histone acetylation neutralizes its positive charge, thereby opening the chromatin structure and making it easier for transcription factors to bind to their target genes, so histone acetylation is always regarded as a transcriptional activation signal (Haberland et al., 2009). HDACs are potential targets 


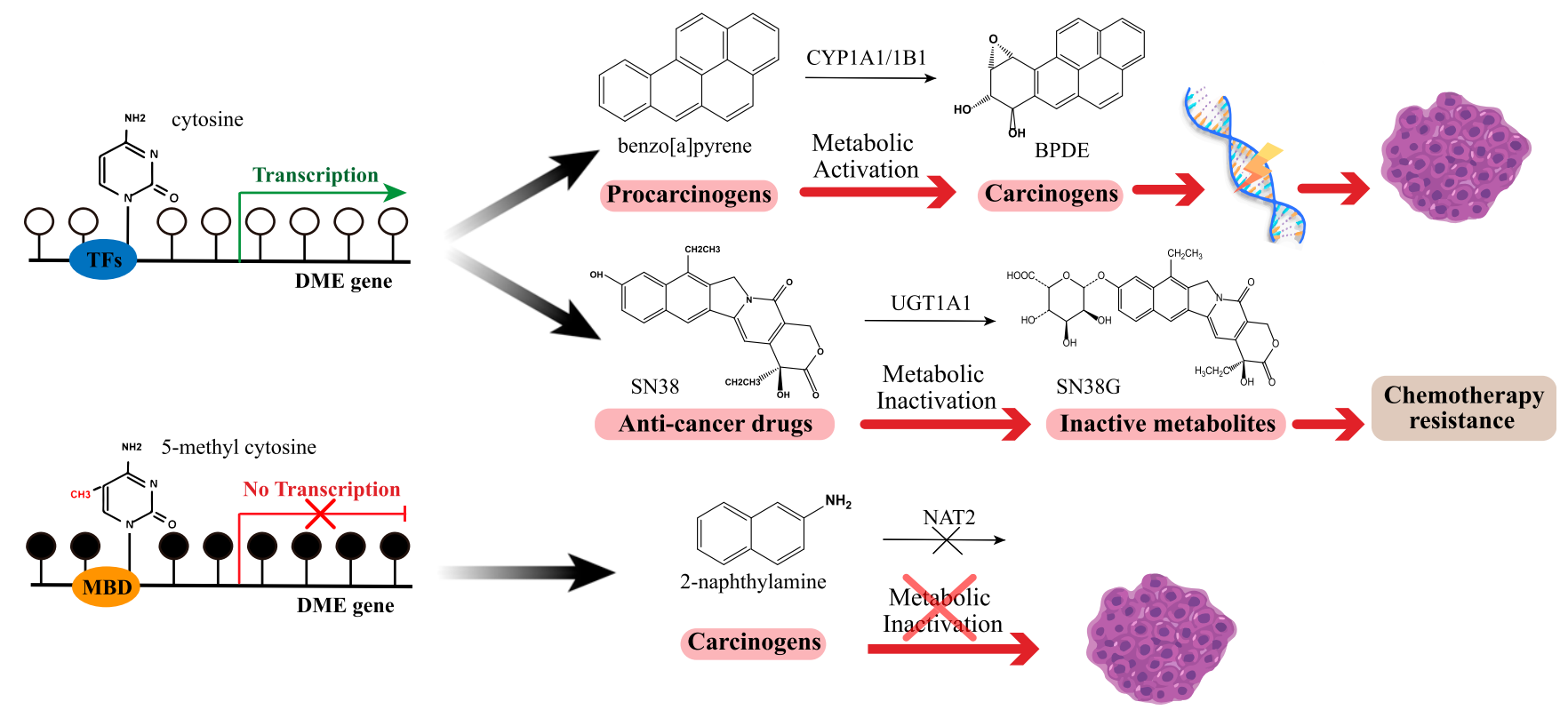

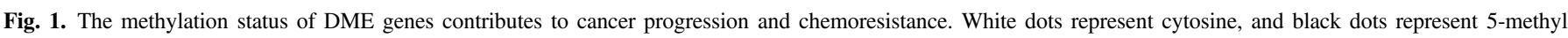
cytosine.

for cancer therapy, and the US Food and Drug Administration has approved several HDAC inhibitors such as Vorinostat and Belinostat (PXD101) for the treatment of cutaneous T-cell lymphoma and peripheral T-cell lymphoma. Furthermore, bromodomain-containing proteins recognize the acetylated lysine residues of histone, which play an essential role in the process of cancer development. Thus, designing small-molecule bromodomain-containing protein inhibitors may be a promising strategy ( $\mathrm{Fu}$ et al., 2015; Yu et al., 2015b). Histone methylation exhibits distinct functions of gene activation or repression with different modification sites (H3K4, H3K9, H3K27, etc.) and methylation states (mono-/di-/tri-methylation) (Barski et al., 2007). Enhancer of zeste homolog 2 is a methyltransferase that can add methyl groups to histone $\mathrm{H} 3$ at lysine 27 (H3K27), thus repressing gene transcription. Disruptor of telomeric silencing 1-like methyltransferase is responsible for $\mathrm{H} 3 \mathrm{~K} 79$ methylation. Now the inhibitors of enhancer of zeste homolog 2 and disruptor of telomeric silencing 1-like are in clinical trials and show potent anticancer capacity (Mohammad et al., 2019).

Although emerging evidence suggests that these histone modifications affect the expression of DMEs in the nontumor environment (Tang and Chen, 2015; Yan et al., 2017), the regulation of histone modification of DMEs in the tumor has not yet been reported. Considering the extensive aberrant histone modifications in cancer and their essential roles, we need to clarify the relationship between histone modification and differential expression patterns of DMEs to provide references to personalized medicine.

$1 \alpha, 25$-dihydroxyvitamin $\mathrm{D} 3(1,25-\mathrm{D} 3)$, the active form of vitamin $\mathrm{D}$, is antiproliferative in lung adenocarcinoma. 1, 25-D3 is catabolized by CYP24A1, which is overexpressed in multiple types of cancer. CYP24A1 mRNA was elevated 8- to 50-fold in lung adenocarcinoma compared with normal tissues. The overexpression of CYP24A1 is much more significant in poorly differentiated cancers, accompanied by lower survival rates (Chen et al., 2011b). In lung adenocarcinoma cells, combined treatment with DNMT inhibitor 5-Aza-dC and HDAC inhibitor Trichostatin A (TSA) increases the CYP24A1 expression and enzyme affinity to its substrate 1, 25-D3. The chromatin immunoprecipitation coupled by quantitative polymerase chain reaction (ChIPqPCR) assay revealed that TSA enriched $\mathrm{H} 3 \mathrm{~K} 4 \mathrm{me} 2$ and $\mathrm{H} 3 \mathrm{~K} 9 \mathrm{ac}$ and simultaneously decreased $\mathrm{H} 3 \mathrm{~K} 9 \mathrm{me} 2$ at the $C Y P 24 A 1$ promoter, thus activating the transcriptional expression of CYP24A1 (Ramnath et al., 2014). In human neuroblastoma cells, histone deacetylase inhibitors such as valproic acid and TSA affect the expression of CYP1A1, CYP1B1, and CYP3A4 (Hřebačková et al., 2009). Another study found that inhibition of the $\beta$-catenin signaling pathway induced the CYP1A1 expression through histone H2AX phosphorylation (Kabátková et al., 2015).

\section{Noncoding RNA}

The term "noncoding RNA" refers to RNA molecules that are transcribed from genome but not translated into proteins, including microRNA (miRNA), long noncoding RNA (lncRNA), and circular RNA (circRNA) (Klingenberg et al., 2017). They can give full play to the function of gene regulation at the transcriptional and posttranscriptional levels. Mature miRNAs are single-stranded ncRNAs of 22-25 nucleotides in length, which are derived from primary miRNA transcripts (Li and Rana, 2014). The mature miRNA must assemble into the RNA-induced silencing complex to target its complementary mRNAs for translational repression or target gene degradation ( $\mathrm{Li}$ et al., 2014). IncRNAs are transcripts longer than 200 nucleotides that have little or no protein-coding capacity, and they are transcribed by RNA polymerase II, capped, spliced, and polyadenylated. IncRNAs can regulate gene expression at different levels, including chromatin modification, transcription, and post-transcriptional processing (Mercer et al., 2009). Emerging evidence indicates the translation potential of lncRNAs with open reading frames, which has been overlooked over a long period (Matsumoto et al., 2017). These polypeptides encoded by lncRNAs may also play a crucial role in cancer occurrence and development, it was reported that a peptide encoded by lncRNA HOXB-AS3 suppresses colon cancer growth through a complex regulatory mechanism (Huang et al., 2017). circRNAs are a novel type of RNA molecule that are different from traditional linear RNAs. They have a closed-loop structure and exist in a lot of eukaryotic transcriptomes ( $\mathrm{Qu}$ et al., 2015). Most circRNAs are composed of exon sequences, which are conserved in different species and have regulatory potency (Memczak et al., 2013). circRNAs are not sensitive to nuclease, which makes them more stable than linear RNA, owing to their closed- 
loop structures. Therefore, circRNAs have more potential to become biomarkers in the screening of cancer (Li et al., 2015a,c). The most common regulatory mechanism of lncRNA and circRNA is acting as the "sponge" of miRNA, which can regulate the target gene through changing miRNA expression (Wang et al., 2010; Yu et al., 2016).

With the development of RNA Sequencing, researchers have obtained the expression profiles of miRNA, IncRNA, and circRNA in different types of cancer and their matched paracancerous normal tissues, such as liver cancer, kidney cancer, and breast cancer. They screen the ncRNAs, which are closely related to the occurrence, development, and prognosis of cancer, providing a new biomarker or target for the diagnosis or treatment of cancer (Xie et al., 2013; Li et al., 2015a,c). At present, the regulation of ncRNA on differentially expressed DMEs in the tumor is still limited in the field of miRNA. The regulation of lncRNA and circRNA needs to be further explored.

Phase I DMEs. Abnormal miRNA expression occurs in lung cancer tissues compared with normal tissues. To clarify the functions of these miRNA, researchers established a tobacco-induced cancer rat model to investigate the relationship between miRNA and the occurrence of early lung cancer. It has been demonstrated that carcinogen could reduce the expression of miR-101, miR-126*, miR-199, and miR-34. These miRNAs overlap with previously published reports on altered miRNA expression in human lung cancer samples, suggesting these four miRNAs may be involved in lung cancer development. Treatment with NNK inhibits miR-126* but induces CYP2A3 expression, an essential enzyme to activate NNK, indicating that miR-126* has the possibility of regulating CYP2A3 (Kalscheuer et al., 2008).

The low expression level of miR-27b may contribute to the high expression of CYP1B1 in the mammary gland(Tsuchiya et al., 2006), thus causing the accumulation of 4-hydroxy estradiol and increasing the risk of breast cancer. In HCC, a report has established a negative correlation between the level of hsa-miR-128-3p, hsa-miR-143-3p, and CYP2C9 expression based on in silico analysis and a series of biochemical assays (Yu et al., 2015a).

Recently, RNA-interfering miRNA materials have been designed to interfere with the expression of DMEs. It was reported that a newly established bioengineered RNA agent (BERA), BERA/miR-27b-3p, can be processed into mature miR-27b-3p in human cells, thus decreasing the expression and metabolic capability of CYP3A4 (Li et al., 2019b).

Phase II DMEs. In prostate cancer, miRNA is causally implicated in post-transcriptional regulation of UGTs. Androgen plays a vital role in the development of prostate cancer. UGT2B15, UGT2B17, and UGT2B28 mediate the biotransformation of androgen in vivo. Reporter gene assays validated that miR-376c, miR-409, and miR-494 could interact with UGT2B17, and miR-331-5p and miR-376c could bind to UGT2B15 (Margaillan et al., 2016). miR-376c can effectively repress UGT2B15 and UGT2B17 expression, accompanied by a consequent decrease in dihydrotestosterone glucuronidation. The expression of UGT2B 15 and UGT2B 17 are negatively related to miR-376c expression but positively correlated to metastasis rate in advanced prostate cancer (Wijayakumara et al., 2015). miR-331-5p is also confirmed to reduce the UGT2B15 mRNA level by targeting its $3^{\prime}$-UTR via canonical and noncanonical pairing (Wijayakumara et al., 2018).

Furthermore, UGT2A1 is responsible for the detoxification of PAHs found in cigarette smoke and exhibits high expression in the lung. A recent study suggested that the UGT2A1 expression level can be regulated by both miR-196a-5p and miR-196b-5p (Sutliff et al., 2019).

In breast cancer, miR-1290 is confirmed to target the $3^{\prime}$-UTR of NAT1 directly, which is positively correlated with the overall survival of patients with breast cancer (Endo et al., 2014). The expression of NAT10 is dysregulated in colorectal cancer, which is validated to be inhibited by miR-7616-5p (Liu et al., 2019). Published studies have identified that
hsa-miR-486-5p and hsa-miR-495-3p decrease the mRNA stability of phase II detoxification enzymes SULT2A1 in HepG2 human hepatocellular carcinoma cell line (Li et al., 2019a).

\section{Summary and Prospect}

DMEs are implicated in the metabolic activation or inactivation of xenobiotics, which are strongly associated with the occurrence and development of cancer. During the development of cancer, the expression level of DMEs changes, thus reducing the detoxification ability of DMEs and promoting cancer progression. In the treatment of cancer, the differentially expressed DMEs may influence the efficacy of anticancer drugs or cause adverse effects by affecting the metabolic process of these drugs.

Epigenetics, especially DNA methylation, plays a critical role in the regulation of differentially expressed DMEs in tumors. DNA methyltransferases are expected to be the target of antitumor drugs. Aberrant DNA methylation modifications are also promising biomarkers in liquid biopsy. A growing body of research suggests that histone modification and ncRNA can regulate the expression of DMEs under nontumor conditions. Histone modification and miRNA have already been proven to participate in the transcriptional regulation of differentially expressed DMEs in lung, liver, prostate, and breast cancer, and the regulatory mechanism in other cancer types needs to be further studied.

Emerging studies showed that the cross talk among various epigenetic mechanisms is noteworthy and needs to be further explored in the regulation of DMEs. Histone modification and DNA methylation always work in concert to regulate gene expression. Methyl-CpG binding proteins recruit protein complex, which contains HDACs and/or histone methyltransferases, inducing the formation of repressive chromatin circumstance (Nan et al., 1998; Fuks et al., 2003). In some instances, the administration of HDAC inhibitors such as TSA and valproic acid reverse the hypermethylation status of certain genes (Ou et al., 2007; Gu et al., 2012). The combination of DNMT and HDAC inhibitors always led to better efficacy, which is considered a good strategy. Histone methylation displays closer ties with DNA methylation. S-adenosyl-1methionine is a universal methyl group donor, so the content of S-adenosyl-1-methionine in cells affects the methylation status of DNA and histone simultaneously. Furthermore, the cross talk between DNA and histone methylation can be mediated by the interaction between DNA and histone methyltransferases (Cedar and Bergman, 2009). DNA hypermethylation status, increased repressive histone modification $\mathrm{H} 3 \mathrm{k} 9 \mathrm{me} 2$, decreased $\mathrm{H} 3 \mathrm{~K} 9 \mathrm{ac}$, and $\mathrm{H} 3 \mathrm{~K} 4 \mathrm{me} 2$ modification at CYP24A1 promoter contribute to the suppression of CYP24A1 in prostate cancer. Combined treatment with DNMT inhibitor DAC and HDAC inhibitor TSA upregulated the CYP24A1 expression, accompanied by increased recruitment of vitamin D receptor to CYP24A1 promoter (Luo et al., 2010). The interplay between miRNA and DNA methylation in gene regulation is also widely reported. The transcription and synthesis of miRNAs can be repressed by DNA methylation, and certain miRNAs can change the DNA methylation status of the gene by targeting DNMTs in return (Fuso et al., 2020). In colorectal cancer, inflammatory factor cytokine interleukin-6 was reported to promote DNMT1 nuclear translocation, and then DNMT1 caused DNA methylation of $\mathrm{CpG}$ islands near miR27b, thus suppressing its transcription. Because of the reduced degradation by miR27b, CYP1B1 showed a high expression level (Patel et al., 2014).

Also, further research is required to clarify if the epigenetic regulations of DMEs contribute to the metabolism of endogenous substrates during cancer progression and its downstream impacts. Elucidating the epigenetic regulatory mechanism of DMEs in tumors can provide a basis for implementing individualized and rationalized 
medication as well as developing new biomarkers and targets for the diagnosis, treatment, and prognosis of cancer.

\section{Authorship Contributions}

Wrote or contributed to the writing of the manuscript: Wang, Yu, Jiang, Zheng, Zeng.

\section{References}

Almazroo OA, Miah MK, and Venkataramanan R (2017) Drug metabolism in the liver. Clin Liver Dis 21:1-20.

Alzahrani AM and Rajendran P (2020) The Multifarious Link between cytochrome P450s and cancer. Oxid Med Cell Longev 2020:3028387.

Barski A, Cuddapah S, Cui K, Roh TY, Schones DE, Wang Z, Wei G, Chepelev I, and Zhao K (2007) High-resolution profiling of histone methylations in the human genome. Cell 129 823-837.

Brodeur CM, Thibault P, Durand M, Perreault JP, and Bisaillon M (2019) Dissecting the expression landscape of cytochromes $\mathrm{P} 450$ in hepatocellular carcinoma: towards novel molecular biomarkers. Genes Cancer 10:97-108.

Carnell DM, Smith RE, Daley FM, Barber PR, Hoskin PJ, Wilson GD, Murray GI, and Everett SA (2004) Target validation of cytochrome P450 CYP1B1 in prostate carcinoma with protein expression in associated hyperplastic and premalignant tissue. Int $J$ Radiat Oncol Biol Phys $\mathbf{5 8}$ 500-509.

Castell JV, Donato MT, and Gómez-Lechón MJ (2005) Metabolism and bioactivation of toxicants in the lung. The in vitro cellular approach. Exp Toxicol Pathol 57 (Suppl 1):189-204.

Cedar H and Bergman Y (2009) Linking DNA methylation and histone modification: patterns and paradigms. Nat Rev Genet 10:295-304.

Chen C, Wei X, Rao X, Wu J, Yang S, Chen F, Ma D, Zhou J, Dackor RT, Zeldin DC, et al. (2011a) Cytochrome P450 $2 \mathrm{~J} 2$ is highly expressed in hematologic malignant diseases and promotes tumor cell growth. J Pharmacol Exp Ther 336:344-355.

Chen G, Kim SH, King AN, Zhao L, Simpson RU, Christensen PJ, Wang Z, Thomas DG, Giordano TJ, Lin L, et al. (2011b) CYP24A1 is an independent prognostic marker of survival in patients with lung adenocarcinoma. Clin Cancer Res 17:817-826.

Chen H, Shen ZY, Xu W, Fan TY, Li J, Lu YF, Cheng ML, and Liu J (2014) Expression of P450 and nuclear receptors in normal and end-stage Chinese livers. World $J$ Gastroenterol 20: $8681-8690$

Chen YW, Kao SY, Wang HJ, and Yang MH (2013) Histone modification patterns correlate with patient outcome in oral squamous cell carcinoma. Cancer 119:4259-4267.

Clouaire T and Stancheva I (2008) Methyl-CpG binding proteins: specialized transcriptional repressors or structural components of chromatin? Cell Mol Life Sci 65:1509-1522.

DiNardo C D, Gharibyan V, Yang H, Wei Y, Pierce S, Kantarjian H M, Garcia-Manero G, and Rytting M (2013) Impact of aberrant DNA methylation patterns including CYP1B1 methylation in adolescents and young adults with acute lymphocytic leukemia. Am J Hematol $\mathbf{8 8}$ (9): 784-789.

Endo Y, Yamashita H, Takahashi S, Sato S, Yoshimoto N, Asano T, Hato Y, Dong Y, Fujii Y, and Toyama $T$ (2014) Immunohistochemical determination of the miR-1290 target arylamine $\mathrm{N}$-acetyltransferase 1 (NAT1) as a prognostic biomarker in breast cancer. BMC Cancer 14:990.

Fan Z, Wang Z, Chen W, Cao Z, and Li Y (2016) Association between the CYP11 family and six cancer types. Oncol Lett 12:35-40.

Fang C, Wei XM, Zeng XT, Wang FB, Weng H, and Long X (2015) Aberrant GSTP1 promoter methylation is associated with increased risk and advanced stage of breast cancer: a metaanalysis of 19 case-control studies. BMC Cancer 15:920.

Fu LL, Tian M, Li X, Li JJ, Huang J, Ouyang L, Zhang Y, and Liu B (2015) Inhibition of BET bromodomains as a therapeutic strategy for cancer drug discovery. Oncotarget 6:5501-5516.

Fujimura T, Takahashi S, Urano T, Kumagai J, Murata T, Takayama K, Ogushi T, Horie-Inoue K, Ouchi Y, Kitamura T, et al. (2009) Expression of cytochrome P450 3A4 and its clinical significance in human prostate cancer. Urology 74:391-397.

Fuks F, Hurd PJ, Wolf D, Nan X, Bird AP, and Kouzarides T (2003) The methyl-CpGbinding protein MeCP2 links DNA methylation to histone methylation. J Biol Chem 278:4035-4040

Fuso A, Raia T, Orticello M, and Lucarelli M (2020) The complex interplay between DNA methylation and miRNAs in gene expression regulation. Biochimie 173:12-16 DOI: 10.1016/ j.biochi.2020.1002.1006

Gagnon JF, Bernard O, Villeneuve L, Têtu B, and Guillemette C (2006) Irinotecan inactivation is modulated by epigenetic silencing of UGT1A1 in colon cancer. Clin Cancer Res 12:1850-1858.

Gajjar K, Martin-Hirsch PL, and Martin FL (2012) CYP1B1 and hormone-induced cancer. Cancer Lett 324:13-30.

Gao J, Wang Z, Wang GJ, Gao N, Li J, Zhang YF, Zhou J, Zhang HX, Wen Q, Jin H, et al. (2018) From hepatofibrosis to hepatocarcinogenesis: higher cytochrome P450 2E1 activity is a potential risk factor. Mol Carcinog 57:1371-1382.

Gao P, Yang X, Xue YW, Zhang XF, Wang Y, Liu WJ, and Wu XJ (2009) Promoter methylation of glutathione S-transferase pil and multidrug resistance gene 1 in bronchioloalveolar carcinoma and its correlation with DNA methyltransferase 1 expression. Cancer 115:3222-3232.

Gu S, Tian Y, Chlenski A, Salwen HR, Lu Z, Raj JU, and Yang Q (2012) Valproic acid shows a potent antitumor effect with alteration of DNA methylation in neuroblastoma. Anticancer Drugs 23:1054-1066.

Guo YY, Xu C, Fang Y, Wang CE, Gao N, Wen Q, and Qiao HL (2019) High CYP2E1 activity aggravates hepatofibrosis by limiting macrophage polarization towards the M2 phenotype. Mol Carcinog 58:1481-1491.

Habano W, Gamo T, Sugai T, Otsuka K, Wakabayashi G, and Ozawa S (2009) CYP1B1, but not CYP1A1, is downregulated by promoter methylation in colorectal cancers. Int J Oncol 34 $1085-1091$

Habano W, Kawamura K, Iizuka N, Terashima J, Sugai T, and Ozawa S (2015) Analysis of DNA methylation landscape reveals the roles of DNA methylation in the regulation of drug metabolizing enzymes. Clin Epigenetics 7:105.

Haberland M, Montgomery RL, and Olson EN (2009) The many roles of histone deacetylases in development and physiology: implications for disease and therapy. Nat Rev Genet 10:32-42.
Hahn RZ, Antunes MV, Verza SG, Perassolo MS, Suyenaga ES, Schwartsmann G, and Linden R (2019) Pharmacokinetic and Pharmacogenetic markers of irinotecan Toxicity. Curr Med Chem 26:2085-2107.

He X and Feng S (2015) Role of metabolic enzymes P450 (CYP) on activating procarcinogen and their polymorphisms on the risk of cancers. Curr Drug Metab 16:850-863.

Henrique R and Jerónimo C (2004) Molecular detection of prostate cancer: a role for GSTP1 hypermethylation. Eur Urol 46:660-669, discussion 669.

Ho JC, Cheung ST, Leung KL, Ng IO, and Fan ST (2004) Decreased expression of cytochrome $\mathrm{P} 4502 \mathrm{E} 1$ is associated with poor prognosis of hepatocellular carcinoma. Int J Cancer 111 494-500.

Hokaiwado N, Takeshita F, Naiki-Ito A, Asamoto M, Ochiya T, and Shirai T (2008) Glutathione $\mathrm{S}$-transferase Pi mediates proliferation of androgen-independent prostate cancer cells. Carcinogenesis 29:1134-1138.

Hřebačková J, Poljaková J, Eckschlager T, Hraběta J, Procházka P, Smutný S, and Stiborová M (2009) Histone deacetylase inhibitors valproate and trichostatin A are toxic to neuroblastoma cells and modulate cytochrome P450 1A1, 1B1 and 3A4 expression in these cells. Interdiscip Toxicol 2:205-210

Hu DG, Marri S, McKinnon RA, Mackenzie PI, and Meech R (2019) Deregulation of the genes that are involved in drug absorption, distribution, metabolism, and excretion in hepatocellular carcinoma. J Pharmacol Exp Ther 368:363-381.

Huang JZ, Chen M, Chen D, Gao XC, Zhu S, Huang H, Hu M, Zhu H, and Yan GR (2017) A peptide encoded by a putative lncRNA HOXB-AS3 suppresses colon cancer growth. Mol Cell 68:171-184.e6.

Imaoka S, Yoneda Y, Sugimoto T, Hiroi T, Yamamoto K, Nakatani T, and Funae Y (2000) CYP4B1 is a possible risk factor for bladder cancer in humans. Biochem Biophys Res Commun 277:776-780.

Ivanov M, Kacevska M, and Ingelman-Sundberg M (2012) Epigenomics and interindividual differences in drug response. Clin Pharmacol Ther 92:727-736.

Jiang JG, Ning YG, Chen C, Ma D, Liu ZJ, Yang S, Zhou J, Xiao X, Zhang XA, Edin ML, et al (2007) Cytochrome p450 epoxygenase promotes human cancer metastasis. Cancer Res 67 6665-6674.

Kabátková M, Zapletal O, Tylichová Z, Neča J, Machala M, Milcová A, Topinka J, Kozubík A, and Vondráček J (2015) Inhibition of $\beta$-catenin signalling promotes DNA damage elicited by benzo[a]pyrene in a model of human colon cancer cells via CYP1 deregulation. Mutagenesis 30 $565-576$.

Kalscheuer S, Zhang X, Zeng Y, and Upadhyaya P (2008) Differential expression of microRNAs in early-stage neoplastic transformation in the lungs of F344 rats chronically treated with the tobacco carcinogen 4-(methylnitrosamino)-1-(3-pyridyl)-1-butanone. Carcinogenesis 29: 2394-2399.

Kamdem LK, Meineke I, Gödtel-Armbrust U, Brockmöller J, and Wojnowski L (2006) Dominan contribution of P450 3A4 to the hepatic carcinogenic activation of aflatoxin B1. Chem Res Toxicol 19:577-586.

Kanwal R, Pandey M, Bhaskaran N, Maclennan GT, Fu P, Ponsky LE, and Gupta S (2014) Protection against oxidative DNA damage and stress in human prostate by glutathione S-transferase P1. Mol Carcinog 53:8-18

Karypidis AH, Olsson M, Andersson SO, Rane A, and Ekström L (2008) Deletion polymorphism of the UGT2B17 gene is associated with increased risk for prostate cancer and correlated to gene expression in the prostate. Pharmacogenomics $J$ 8:147-151.

Kim SJ, Kang HS, Jung SY, Min SY, Lee S, Kim SW, Kwon Y, Lee KS, Shin KH, and Ro J (2010) Methylation patterns of genes coding for drug-metabolizing enzymes in tamoxifenresistant breast cancer tissues. J Mol Med (Berl) 88:1123-1131.

Klingenberg M, Matsuda A, Diederichs S, and Patel T (2017) Non-coding RNA in hepatocellular carcinoma: mechanisms, biomarkers and therapeutic targets. J Hepatol 67:603-618.

Kumagai J, Fujimura T, Takahashi S, Urano T, Ogushi T, Horie-Inoue K, Ouchi Y, Kitamura T, Muramatsu M, Blumberg B, et al. (2007) Cytochrome P450 2B6 is a growth-inhibitory and prognostic factor for prostate cancer. Prostate 67:1029-1037.

Lachenmayer A, Toffanin S, Cabellos L, Alsinet C, Hoshida Y, Villanueva A, Minguez B, Tsai HW, Ward SC, Thung S, et al. (2012) Combination therapy for hepatocellular carcinoma: additive preclinical efficacy of the HDAC inhibitor panobinostat with sorafenib. J Hepatol 56: 1343-1350.

Leclerc J, Courcot-Ngoubo Ngangue E, Cauffiez C, Allorge D, Pottier N, Lafitte JJ, Debaert M, Jaillard S, Broly F, and Lo-Guidice JM (2011) Xenobiotic metabolism and disposition in human lung: transcript profiling in non-tumoral and tumoral tissues. Biochimie 93: $1012-1027$.

Leclerc J, Tournel G, Courcot-Ngoubo Ngangue E, Pottier N, Lafitte JJ, Jaillard S, Mensier E, Lhermitte M, Broly F, and Lo-Guidice JM (2010) Profiling gene expression of whole cytochrome P450 superfamily in human bronchial and peripheral lung tissues: differential expression in non-small cell lung cancers. Biochimie 92:292-306.

Lévesque E, Labriet A, Hovington H, Allain EP, Melo-Garcia L, Rouleau M, Brisson H, Turcotte V, Caron P, Villeneuve L, et al. (2020) Alternative promoters control UGT2B17-dependent androgen catabolism in prostate cancer and its influence on progression. $\mathrm{Br} J$ Cancer 122: $1068-1076$.

Li D, Knox B, Chen S, Wu L, Tolleson WH, Liu Z, Yu D, Guo L, Tong W, and Ning B (2019a) MicroRNAs hsa-miR-495-3p and hsa-miR-486-5p suppress basal and rifampicin-induced expression of human sulfotransferase 2A1 (SULT2A1) by facilitating mRNA degradation. Biochem Pharmacol 169:113617.

Li J, Tan S, Kooger R, Zhang C, and Zhang Y (2014) MicroRNAs as novel biological targets for detection and regulation. Chem Soc Rev 43:506-517.

Li J, Yang J, Zhou P, Le Y, Zhou C, Wang S, Xu D, Lin HK, and Gong Z (2015a) Circular RNAs in cancer: novel insights into origins, properties, functions and implications. Am J Cancer Res $\mathbf{5}$ : $472-480$.

Li MY, Liu Y, Liu LZ, Kong AW, Zhao Z, Wu B, Long X, Wu J, Ng CS, Wan IY, et al. (2015b) Estrogen receptor alpha promotes smoking-carcinogen-induced lung carcinogenesis via cytochrome P450 1B1. J Mol Med (Berl) 93:1221-1233.

Li P, Chen S, Chen H, Mo X, Li T, Shao Y, Xiao B, and Guo J (2015c) Using circular RNA as a novel type of biomarker in the screening of gastric cancer. Clin Chim Acta 444: 132-136.

Li X, Tian Y, Tu MJ, Ho PY, Batra N, and Yu AM (2019b) Bioengineered miR-27b-3p and miR$328-3 \mathrm{p}$ modulate drug metabolism and disposition via the regulation of target ADME gene expression. Acta Pharm Sin B 9:639-647. 
Li Y, Cai Y, Chen H, and Mao L (2018) Clinical significance and association of GSTP1 hypermethylation with hepatocellular carcinoma: a meta-analysis. J Cancer Res Ther 14 (Supplement): S486-S489.

Li Z and Rana TM (2014) Therapeutic targeting of microRNAs: current status and future challenges. Nat Rev Drug Discov 13:622-638.

Lindley C, Hamilton G, McCune JS, Faucette S, Shord SS, Hawke RL, Wang H, Gilbert D, Jolley S, Yan B, et al. (2002) The effect of cyclophosphamide with and without dexamethasone on cytochrome P450 3A4 and 2B6 in human hepatocytes. Drug Metab Dispos 30:814-822.

Linhart K, Bartsch H, and Seitz HK (2014) The role of reactive oxygen species (ROS) and cytochrome P-450 2E1 in the generation of carcinogenic etheno-DNA adducts. Redox Biol 3: $56-62$.

Litwin MS and Tan HJ (2017) The diagnosis and treatment of prostate cancer: a review. JAMA 317: $2532-2542$.

Liu F, Luo LM, Wei YG, Li B, Wang WT, Wen TF, Yang JY, Xu MQ, and Yan LN (2015) Polymorphisms of the CYP1B1 gene and hepatocellular carcinoma risk in a Chinese population. Gene 564:14-20.

Liu Y, Zheng X, Yu Q, Wang H, Tan F, Zhu Q, Yuan L, Jiang H, Yu L, and Zeng S (2016) Epigenetic activation of the drug transporter OCT2 sensitizes renal cell carcinoma to oxaliplatin. Sci Transl Med 8:348ra97.

Liu Z, Liu X, Li Y, Ren P, Zhang C, Wang L, Du X, and Xing B (2019) miR-6716-5p promotes metastasis of colorectal cancer through downregulating NAT10 expression. Cancer Manag Res 11:5317-5332

Lu L, Zhou J, Shi J, Peng XJ, Qi XX, Wang Y, Li FY, Zhou FY, Liu L, and Liu ZQ (2015) Drugmetabolizing activity, protein and gene expression of UDP-glucuronosyltransferases are significantly altered in hepatocellular carcinoma patients. PLoS One 10:e 0127524.

Luger K, Dechassa ML, and Tremethick DJ (2012) New insights into nucleosome and chromatin structure: an ordered state or a disordered affair? Nat Rev Mol Cell Biol 13:436-447.

Luo W, Karpf AR, Deeb KK, Muindi JR, Morrison CD, Johnson CS, and Trump DL (2010) Epigenetic regulation of vitamin D 24-hydroxylase/CYP24A1 in human prostate cancer. Cancer Res 70:5953-5962.

Mahon KL, Qu W, Lin HM, Spielman C, Cain D, Jacobs C, Stockler MR, Higano CS, de Bono JS, Chi KN, et al. (2019) Serum free methylated glutathione S-transferase 1 DNA levels, survival, and response to docetaxel in metastatic, castration-resistant prostate cancer: post hoc analyses of data from a phase 3 trial. Eur Urol 76:306-312.

Maldonado L, Brait M, Loyo M, Sullenberger L, Wang K, Peskoe SB, Rosenbaum E, Howard R, Toubaji A, Albadine R, et al. (2014) GSTP1 promoter methylation is associated with recurrence in early stage prostate cancer. J Urol 192:1542-1548.

Margaillan G, Lévesque É, and Guillemette C (2016) Epigenetic regulation of steroid inactivating UDP-glucuronosyltransferases by microRNAs in prostate cancer. J Steroid Biochem Mol Biol 155 (Pt A):85-93.

Margaillan G, Rouleau M, Fallon JK, Caron P, Villeneuve L, Turcotte V, Smith PC, Joy MS, and Guillemette C (2015) Quantitative profiling of human renal UDP-glucuronosyltransferases and glucuronidation activity: a comparison of normal and tumoral kidney tissues. Drug Metab Dispos 43:611-619.

Marques Maud, Laflamme Liette, and Gaudreau Luc (2013) Estrogen receptor $\alpha$ can selectively repress dioxin receptor-mediated gene expression by targeting DNA methylation. Nucleic Acids Res 41 (17):8094-8106.

Matsumoto A, Pasut A, Matsumoto M, Yamashita R, Fung J, Monteleone E, Saghatelian A, Nakayama KI, Clohessy JG, and Pandolfi PP (2017) mTORC1 and muscle regeneration are regulated by the LINC00961-encoded SPAR polypeptide. Nature 541:228-232.

McFadyen MC, Breeman S, Payne S, Stirk C, Miller ID, Melvin WT, and Murray GI (1999) Immunohistochemical localization of cytochrome P450 CYP1B1 in breast cancer with monoclonal antibodies specific for CYP1B1. J Histochem Cytochem 47:1457-1464.

Memczak S, Jens M, Elefsinioti A, Torti F, Krueger J, Rybak A, Maier L, Mackowiak SD, Gregersen LH, Munschauer M, et al. (2013) Circular RNAs are a large class of animal RNAs with regulatory potency. Nature 495:333-338.

Mercer TR, Dinger ME, and Mattick JS (2009) Long non-coding RNAs: insights into functions. Nat Rev Genet 10:155-159.

Mitsui Y, Chang I, Kato T, Hashimoto Y, Yamamura S, Fukuhara S, Wong DK, Shiina M, ImaiSumida M, Majid S, et al. (2016) Functional role and tobacco smoking effects on methylation of CYP1A1 gene in prostate cancer. Oncotarget 7:49107-49121.

Mohammad HP, Barbash O, and Creasy CL (2019) Targeting epigenetic modifications in cancer therapy: erasing the roadmap to cancer. Nat Med 25:403-418.

Moore LD, Le T, and Fan G (2013) DNA methylation and its basic function. Neuropsychopharmacology 38:23-38.

Moorthy B, Chu C, and Carlin DJ (2015) Polycyclic aromatic hydrocarbons: from metabolism to lung cancer. Toxicol Sci 145:5-15.

Mutka SC, Green LH, Verderber EL, Richards JP, Looker DL, Chlipala EA, and Rosenthal GJ (2012) ADH IB expression, but not ADH III, is decreased in human lung cancer. PLoS One 7 e52995.

Nakayama M, Gonzalgo ML, Yegnasubramanian S, Lin X, De Marzo AM, and Nelson WG (2004) GSTP1 CpG island hypermethylation as a molecular biomarker for prostate cancer. J Cell Biochem 91:540-552.

Nan X, Ng HH, Johnson CA, Laherty CD, Turner BM, Eisenman RN, and Bird A (1998) Transcriptional repression by the methyl-CpG-binding protein $\mathrm{MeCP} 2$ involves a histone deacetylase complex. Nature 393:386-389.

Nebert DW and Dalton TP (2006) The role of cytochrome P450 enzymes in endogenous signalling pathways and environmental carcinogenesis. Nat Rev Cancer 6:947-960.

Nie J, Liu L, Li X, and Han W (2014) Decitabine, a new star in epigenetic therapy: the clinical application and biological mechanism in solid tumors. Cancer Lett 354:12-20.

Ou JN, Torrisani J, Unterberger A, Provençal N, Shikimi K, Karimi M, Ekström TJ, and Szyf M (2007) Histone deacetylase inhibitor Trichostatin A induces global and gene-specific DNA demethylation in human cancer cell lines. Biochem Pharmacol 73:1297-1307.

Pâquet S, Fazli L, Grosse L, Verreault M, Têtu B, Rennie PS, Bélanger A, and Barbier O (2012) Differential expression of the androgen-conjugating UGT2B15 and UGT2B17 enzymes in prostate tumor cells during cancer progression. J Clin Endocrinol Metab 97:E428-E432.

Pastina I, Giovannetti E, Chioni A, Sissung TM, Crea F, Orlandini C, Price DK, Cianci C, Figg WD, Ricci S, et al. (2010) Cytochrome 450 1B1 (CYP1B1) polymorphisms associated with response to docetaxel in Castration-Resistant Prostate Cancer (CRPC) patients. BMC Cancer 10: 511.
Patel SA, Bhambra U, Charalambous MP, David RM, Edwards RJ, Lightfoot T, Boobis AR, and Gooderham NJ (2014) Interleukin-6 mediated upregulation of CYP1B1 and CYP2E1 in colorectal cancer involves DNA methylation, miR27b and STAT3. Br J Cancer 111:2287-2296.

Pathania S, Bhatia R, Baldi A, Singh R, and Rawal RK (2018) Drug metabolizing enzymes and their inhibitors' role in cancer resistance. Biomed Pharmacother 105:53-65.

Peng DF, Razvi M, Chen H, Washington K, Roessner A, Schneider-Stock R, and El-Rifai W (2009) DNA hypermethylation regulates the expression of members of the Mu-class glutathione $\mathrm{S}$-transferases and glutathione peroxidases in Barrett's adenocarcinoma. Gut 58:5-15.

Piccolo FM and Fisher AG (2014) Getting rid of DNA methylation. Trends Cell Biol 24:136-143. Pljesa-Ercegovac M, Savic-Radojevic A, Matic M, Coric V, Djukic T, Radic T, and Simic T (2018) Glutathione transferases: potential targets to overcome chemoresistance in solid tumors. Int I Mol Sci 19:3785.

Putluri N, Shojaie A, Vasu VT, Vareed SK, Nalluri S, Putluri V, Thangjam GS, Panzitt K, Tallman $\mathrm{CT}$, Butler C, et al. (2011) Metabolomic profiling reveals potential markers and bioprocesses altered in bladder cancer progression. Cancer Res 71:7376-7386.

Qu S, Yang X, Li X, Wang J, Gao Y, Shang R, Sun W, Dou K, and Li H (2015) Circular RNA: a new star of noncoding RNAs. Cancer Lett 365:141-148.

Ramnath N, Nadal E, Jeon CK, Sandoval J, Colacino J, Rozek LS, Christensen PJ, Esteller M, Beer DG, and Kim SH (2014) Epigenetic regulation of vitamin D metabolism in human lung adenocarcinoma. $J$ Thorac Oncol 9:473-482.

Revill K, Wang T, Lachenmayer A, Kojima K, Harrington A, Li J, Hoshida Y, Llovet JM, and Powers S (2013) Genome-wide methylation analysis and epigenetic unmasking identify tumor suppressor genes in hepatocellular carcinoma. Gastroenterology 145:1424-1435-25.

Rodrigues-Lima F, Dairou J, Busi F, and Dupret JM (2010) Human arylamine N-acetyltransferase 1: a drug-metabolizing enzyme and a drug target? Curr Drug Targets 11:759-766.

Sawers L, Ferguson MJ, Ihrig BR, Young HC, Chakravarty P, Wolf CR, and Smith G (2014) Glutathione S-transferase P1 (GSTP1) directly influences platinum drug chemosensitivity in ovarian tumour cell lines. Br J Cancer 111:1150-1158.

Schmelzle M, Dizdar L, Matthaei H, Baldus SE, Wolters J, Lindenlauf N, Bruns I, Cadeddu RP, Kröpil F, Topp SA, et al. (2011) Esophageal cancer proliferation is mediated by cytochrome P450 2C9 (CYP2C9). Prostaglandins Other Lipid Mediat 94:25-33.

Schnekenburger M, Karius T, and Diederich M (2014) Regulation of epigenetic traits of the glutathione S-transferase P1 gene: from detoxification toward cancer prevention and diagnosis. Front Pharmacol 5:170.

Siegel RL, Miller KD, and Jemal A (2019) Cancer statistics, 2019. CA Cancer J Clin 69:7-34 Slattery ML, Samowtiz W, Ma K, Murtaugh M, Sweeney C, Levin TR, and Neuhausen S (2004) CYP1A1, cigarette smoking, and colon and rectal cancer. Am J Epidemiol 160: $842-852$.

Sohn OS, Fiala ES, Requeijo SP, Weisburger JH, and Gonzalez FJ (2001) Differential effects of CYP2E1 status on the metabolic activation of the colon carcinogens azoxymethane and methylazoxymethanol. Cancer Res 61:8435-8440.

Su WH, Chao CC, Yeh SH, Chen DS, Chen PJ, and Jou YS (2007) OncoDB.HCC: an integrated oncogenomic database of hepatocellular carcinoma revealed aberrant cancer target genes and loci. Nucleic Acids Res 35:D727-D731.

Sutliff AK, Watson CJW, Chen G, and Lazarus P (2019) Regulation of UGT2A1 by miR-196a-5p and miR-196b-5p. J Pharmacol Exp Ther 369:234-243.

Tan AC, Jimeno A, Lin SH, Wheelhouse J, Chan F, Solomon A, Rajeshkumar NV, Rubio-Viqueira B, and Hidalgo M (2009) Characterizing DNA methylation patterns in pancreatic cancer genome. Mol Oncol 3:425-438.

Tan SK, Pastori C, Penas C, Komotar RJ, Ivan ME, Wahlestedt C, and Ayad NG (2018) Serum long noncoding RNA HOTAIR as a novel diagnostic and prognostic biomarker in glioblastoma multiforme. Mol Cancer 17:74.

Tang SC, Wu MF, Wong RH, Liu YF, Tang LC, Lai CH, Hsu CP, and Ko JL (2011) Epigenetic mechanisms for silencing glutathione S-transferase $\mathrm{m} 2$ expression by hypermethylated specificity protein 1 binding in lung cancer. Cancer 117:3209-3221.

Tang X and Chen S (2015) Epigenetic regulation of cytochrome P450 enzymes and clinical implication. Curr Drug Metab 16:86-96.

Tang X, Ge L, Chen Z, Kong S, Liu W, Xu Y, Zeng S, and Chen S (2016) Methylation of the constitutive androstane receptor is involved in the suppression of CYP2C19 in hepatitis B virusassociated hepatocellular carcinoma. Drug Metab Dispos 44:1643-1652.

Tchou JC, Lin X, Freije D, Isaacs WB, Brooks JD, Rashid A, De Marzo AM, Kanai Y, Hirohash S, and Nelson WG (2000) GSTP1 CpG island DNA hypermethylation in hepatocellular carcinomas. Int J Oncol 16:663-676.

Thomas JH (2007) Rapid birth-death evolution specific to xenobiotic cytochrome P450 genes in vertebrates. PLoS Genet 3:e67.

Tokizane T, Shiina H, Igawa M, Enokida H, Urakami S, Kawakami T, Ogishima T, Okino ST, L LC, Tanaka Y, et al. (2005) Cytochrome P450 1B1 is overexpressed and regulated by hypomethylation in prostate cancer. Clin Cancer Res 11:5793-5801.

Tsuchiya Yuki, Nakajima Miki, Takagi Shingo, Taniya Takao, and Yokoi Tsuyoshi (2006) MicroRNA regulates the expression of human cytochrome P450 1B1. Cancer Res 66 (18): 9090-9098.

Ul-Islam S, Ahmed MB, Shehzad A, Ul-Islam M, and Lee YS (2018) Failure of chemotherapy in hepatocellular carcinoma due to impaired and dysregulated primary liver drug metabolizing enzymes and drug transport proteins: what to do? Curr Drug Metab 19:819-829.

Wang J, Liu X, Wu H, Ni P, Gu Z, Qiao Y, Chen N, Sun F, and Fan Q (2010) CREB up-regulates long non-coding RNA, HULC expression through interaction with microRNA-372 in liver cancer. Nucleic Acids Res 38:5366-5383.

Weinberg OK, Marquez-Garban DC, Fishbein MC, Goodglick L, Garban HJ, Dubinett SM, and Pietras RJ (2005) Aromatase inhibitors in human lung cancer therapy. Cancer Res 65: 11287-11291

Weng MW, Hsiao YM, Chiou HL, Yang SF, Hsieh YS, Cheng YW, Yang CH, and Ko JL (2005) Alleviation of benzo[a]pyrene-diolepoxide-DNA damage in human lung carcinoma by glutathione S-transferase M2. DNA Repair (Amst) 4:493-502.

Widschwendter M, Siegmund KD, Müller HM, Fiegl H, Marth C, Müller-Holzner E, Jones PA, and Laird PW (2004) Association of breast cancer DNA methylation profiles with hormone receptor status and response to tamoxifen. Cancer Res 64:3807-3817.

Wijayakumara DD, Hu DG, Meech R, McKinnon RA, and Mackenzie PI (2015) Regulation of human UGT2B15 and UGT2B17 by miR-376c in prostate cancer cell lines. J Pharmacol Exp Ther 354:417-425. 
Wijayakumara DD, Mackenzie PI, McKinnon RA, Hu DG, and Meech R (2018) Regulation of UDP-glucuronosyltransferase $2 \mathrm{~B} 15$ by miR-331-5p in prostate cancer cells involves canonical and noncanonical target sites. J Pharmacol Exp Ther 365:48-59.

Xie FW, Peng YH, Wang WW, Chen X, Chen X, Li J, Yu ZY, and Ouyang XN (2014) Influence of UGT1A1 gene methylation level in colorectal cancer cells on the sensitivity of the chemotherapy drug CPT-11. Biomed Pharmacother 68:825-831.

Xie H, Ma H, and Zhou D (2013) Plasma HULC as a promising novel biomarker for the detection of hepatocellular carcinoma. BioMed Res Int 2013:136106.

Xu RH, Wei W, Krawczyk M, Wang W, Luo H, Flagg K, Yi S, Shi W, Quan Q, Li K, et al. (2017) Circulating tumour DNA methylation markers for diagnosis and prognosis of hepatocellula carcinoma. Nat Mater 16:1155-1161.

Yager JD (2000) Endogenous estrogens as carcinogens through metabolic activation. J Natl Cancer Inst Monogr 2000:67-73.

Yan L, Wang Y, Liu J, Nie Y, Zhong XB, Kan Q, and Zhang L (2017) Alterations of histone modifications contribute to pregnane $\mathrm{X}$ receptor-mediated induction of CYP3A4 by rifampicin. Mol Pharmacol 92:113-123.

Yan T, Gao S, Peng X, Shi J, Xie C, Li Q, Lu L, Wang Y, Zhou F, Liu Z, et al. (2015a) Significantly decreased and more variable expression of major CYPs and UGTs in liver microsomes prepared from HBV-positive human hepatocellular carcinoma and matched pericarcinomatous tissues determined using an isotope label-free UPLC-MS/MS method. Pharm Res 32:1141-1157.

Yan T, Lu L, Xie C, Chen J, Peng X, Zhu L, Wang Y, Li Q, Shi J, Zhou F, et al. (2015b) Severely impaired and dysregulated cytochrome P450 expression and activities in hepatocellular carcinoma: implications for personalized treatment in patients. Mol Cancer Ther 14:2874-2886.

Yu D, Green B, Marrone A, Guo Y, Kadlubar S, Lin D, Fuscoe J, Pogribny I, and Ning B (2015a) Suppression of CYP2C9 by microRNA hsa-miR-128-3p in human liver cells and association with hepatocellular carcinoma. Sci Rep 5:8534.

Yu L, Gong X, Sun L, Zhou Q, Lu B, and Zhu L (2016) The circular RNA Cdr1as act as an oncogene in hepatocellular carcinoma through targeting miR-7 expression. PLoS One 11: e0158347.
Yu L, Wang Z, Zhang Z, Ren X, Lu X, and Ding K (2015b) Small-molecule BET inhibitors in clinical and preclinical development and their therapeutic potential. Curr Top Med Chem 15:776-794.

Yu MW, Pai CI, Yang SY, Hsiao TJ, Chang HC, Lin SM, Liaw YF, Chen PJ, and Chen CJ (2000) Role of N-acetyltransferase polymorphisms in hepatitis B related hepatocellular carcinoma: impact of smoking on risk. Gut 47:703-709.

Yu W, Chai H, Li Y, Zhao H, Xie X, Zheng H, Wang C, Wang X, Yang G, Cai X, et al. (2012) Increased expression of CYP4Z1 promotes tumor angiogenesis and growth in human breast cancer. Toxicol Appl Pharmacol 264:73-83.

Zanger UM, Klein K, Thomas M, Rieger JK, Tremmel R, Kandel BA, Klein M, and Magdy T (2014) Genetics, epigenetics, and regulation of drug-metabolizing cytochrome p450 enzymes. Clin Pharmacol Ther 95:258-261.

Zanger UM and Schwab M (2013) Cytochrome P450 enzymes in drug metabolism: regulation of gene expression, enzyme activities, and impact of genetic variation. Pharmacol Ther 138 103-141.

Zhang M, Wang Q, Wan KW, Ahmed W, Phoenix DA, Zhang Z, Elrayess MA, Elhissi A, and Sun $X$ (2019) Liposome mediated-CYP1A1 gene silencing nanomedicine prepared using lipid filmcoated proliposomes as a potential treatment strategy of lung cancer. Int J Pharm 566:185-193. Zhou X, Jiao D, Dou M, Chen J, Li Z, Li Y, Liu J, and Han X (2019) Association of glutathione-Stransferase $\mathrm{p} 1$ gene promoter methylation and the incidence of prostate cancer: a systematic review and meta-analysis. J Cancer Res Clin Oncol 145:1939-1948.

Address correspondence to: Dr. Su Zeng, Institute of Drug Metabolism and Pharmaceutical Analysis, Zhejiang Province Key Laboratory of Anti-cancer Drug Research, College of Pharmaceutical Sciences, Zhejiang University, Hangzhou, China. E-mail: zengsu@zju.edu.cn; or Dr. Xiaoli Zheng, Hangzhou Cancer Institution, Hangzhou Cancer Hospital, Hangzhou, China. E-mail: gezixll@ hotmail.com 